\title{
PENGARUH COUNTRY OF ORIGIN, BRAND IMAGE DAN BRAND AWARENESS TERHADAP PURCHASE INTENTION
}

\author{
Thania Pramitha \\ Program Studi Magister Manajemen Universitas Tarumanagara \\ thania.117191043@stu.untar.ac.id
}

Masuk : 30-11-2020, revisi : 21-12-2020, diterima untuk diterbitkan : 21-12-2020

\begin{abstract}
Purchase intention is an intention that arises in a person before making a purchase of a product based on experience in using the product, then based on an assessment of the product that has been proven before or can also occur because of an assessment of external factors that affect the purchase decision process. The purpose of this study is to determine the country of origin, brand image, and brand awareness have a positive influence on the purchase intention. This research is a customer who knows about those skincare products and lives in Jakarta. The sample in this study was 212 people using the convenience sampling technique. The data collection technique was carried out by distributing questionnaires using Google Forms through Whatsapp and Line. Data were analyzed using SEM with PLS-SEM analysis media. The results in this study indicate that country of origin and brand awareness affect purchase intention positively and significantly, but the brand image doesn't affect purchase intention.
\end{abstract}

Keywords: Purchase Intention, Brand Awareness, Brand Image, Country of Origin

Abstrak: Purchase intention adalah intensi yang timbul dalam diri seseorang sebelum melakukan pembelian terhadap suatu produk berdasarkan pengalaman dalam menggunakan produk tersebut, lalu berdasarkan penilaian atas suatu produk tersebut yang sudah dibuktikan sebelumnya atau dapat pula terjadi karena adanya penilaian dari faktor eskternal sehingga mempengaruhi proses keputusan pembelian. Tujuan dari penelitian ini adalah untuk mengetahui apakah brand image dan brand awareness memiliki pengaruh positif terhadap purchase intention. Sampel penelitian ini adalah customer yang mengetahui produk skincare tersebut dan berdomisili di Jakarta. Sampel pada penelitian ini adalah sebanyak 212 orang dengan menggunakan teknik convenience sampling. Teknik pengumpulan data dilakukan dengan menyebarkan kuesioner menggunakan Google Form melalui media Whatsapp dan Line. Data dianalisis menggunakan SEM dengan media analisis PLS-SEM. Hasil pada penelitian ini menunjukkan bahwa country of origin dan brand awareness mempengaruhi purchase intention secara positif dan signifikan, namun brand image tidak mempengaruhi purchase intention.

Kata Kunci: Purchase Intention, Brand Awareness, Brand Image, Country of Origin

\section{PENDAHULUAN}

Dewasa ini, globalisasi sudah menjadi bagian yang tak terpisahkan di dalam kehidupan sosial, ekonomi, dan budaya. Salah satu ciri globalisasi menurut Winarno (2010, p. 17) adalah "bahwa dunia dan pasar-pasar kini terintegrasi dan terkoneksi satu sama lain dalam lingkungan global yang tanpa batas territorial negara". Dari pernyataan tersebut dapat disimpulkan bahwa globalisasi sudah menghapus sekat-sekat antar negara yang menyebabkan semakin mudahnya kita untuk melakukan pertukaran informasi, budaya, bisnis, dan lain-lain. Salah satu dampak globalisasi pada bidang ekonomi yaitu memberikan kemudahan bagi produk luar negeri untuk masuk ke dalam negeri (impor). Dampak globalisasi pada bidang budaya adalah terhadap tren kecantikan yang makin terasa di Indonesia, yaitu produk kecantikan dari luar negeri. Jika dilihat dari negara asal produk, dilakukan survei bahwa wanita paling menyukai produk yang 
berasal dari Korea Selatan sebesar 46\%, lalu menyukai produk asal Indonesia sebesar 34\%, dan yang terakhir memilih produk asal Jepang sebesar 21\% (Zap Clinic, 2018). Menurut Zap Clinic (2018), produk yang paling sering digunakan setiap hari adalah Laneige (Korea Selatan) sebesar 7,7\%, The Body Shop (Korea Selatan) sebesar 5,5\%, Innisfree (Korea Selatan) sebesar 4,6\% dan Nature Republic (Korea Selatan) sebesar 4,2\%. Sehubungan adanya persaingan antar kosmetik luar negeri di Indonesia ini, maka penting untuk meneliti apa saja yang mempengaruhi purchase intention dari konsumen. Purchase intention itu sendiri adalah sesuatu yang timbul setelah menerima rangsangan dari produk yang dilihatnya, dari sana timbul ketertarikan untuk mencoba produk tersebut sampai akhirnya timbul keinginan untuk membeli agar dapat memilikinya (Kotler \& Keller, 2012).

Terdapat beberapa variabel yang dapat mempengaruhi purchase intention. Menurut Cho dan Haliun (2015), purchase intention dipengaruhi oleh country of origin dan product evaluation. Sementara menurut Parkvithee dan Miranda (2012), purchase intention dipengaruhi oleh country of origin, brand equity dan purchase involvement. Lebih lanjut menurut Ghaizani, Pangestuti dan Rahma (2018), variabel yang mempengaruhi purchase intention adalah country of origin dan brand image. Adapun menurut Kim dan Chun (2017), variabel brand image, brand evaluation dan country of origin memiliki pengaruh terhadap purchase intention. Lebih lanjut menurut Santoso, Erdiansyah dan Pribadi (2019), purchase intention dipengaruhi oleh brand image dan brand awareness.

Salah satu variabel yang mempengaruhi purchase intention adalah country of origin. Salah satu efek dari country of origin adalah meningkatkan stimulus untuk mencari informasi lain tentang produk tersebut dan memainkan peran penting dalam membentuk purchase intention seorang konsumen (Hong \& Wyer, Jr., 2017). Selain country of origin, brand image juga dapat mempengaruhi purchase intention. Menurut Kotler dan Keller (2012), brand image yang efektif itu akan memberikan tiga hal yaitu; memantapkan karakter produk dan usulan nilai; menyampaikan karakter tersebut dengan cara yang berbeda sehingga tidak akan dikacaukan oleh produk pesaing dan memberikan kekuatan emosional yang lebih dari sekedar citra biasa. Selain country of origin dan brand image, faktor brand awareness juga dapat mempengaruhi purchase intention. Menurut Kotler dan Keller (2012), brand awareness dapat dijadikan sebagai indikator untuk mengetahui seberapa jauh kesadaran konsumen terhadap suatu merek.

Tujuan penelitian ini adalah untuk menguji secara empiris pengaruh country of origin, brand image dan brand awareness terhadap purchase intention. Hasil penelitian ini diharapkan dapat memberikan masukan dan informasi serta bahan pertimbangan bagi perusahaan untuk evaluasi dalam menentukan strategi bisnis yang tepat dan efektif di masa yang akan datang dalam meningkatkan penjualan produk serta meningkatkan intensi konsumen.

\section{TINJAUAN PUSTAKA}

\section{Country of Origin}

Berdasarkan Hamzaoui dan Merunka (2006, p. 202), "a country's image is a unit of perception that includes various state associations, such as their knowledge or thoughts about the characteristics of a country, its people, their habits and behavior and related products". Berdasarkan uraian tersebut dapat disimpulkan bahwa country of origin merupakan negara asal yang mempengaruhi persepsi atau pandangan seseorang terhadap suatu produk. Country of origin memberikan citra penilaian dan karakteristik tersendiri dari suatu produk atau dalam kata lain merupakan bayangan serta image sebuah produk yang dipicu oleh asal negara produk tersebut.

\section{Brand Image}

Menurut Keller (2013, p. 73), brand image adalah “consumers' perceptions about a brand, as reflected by the brand associations held in consumer memory". Berdasarkan definisi tersebut dapat disimpulkan bahwa brand image merupakan sesuatu yang tertanam dalam benak 
konsumen mengenai suatu produk bukan hanya sekedar merek dari produk tersebut namun juga mendefinisikan atas kualitas produk tersebut sehingga dapat tertanam dalam pemikiran konsumen apabila akan melakukan pembelian atas produk tersebut. Brand image atas suatu produk juga menjadi hal yang membedakan produk satu dengan produk lainnya.

\section{Brand Awareness}

Menurut Rossiter dan Percy (2014, p. 113), definisi dari brand awareness adalah "the ability of buyers to recognize and mention brands without their categories in detail to buy something". Berdasarkan definisi di atas, maka dapat disimpulkan bahwa brand awareness merupakan tujuan umum dari komunikasi pemasaran, brand awareness menunjukkan pengetahuan konsumen terhadap eksistensi suatu brand dimana ditunjukkan dengan tingkat kesadaran konsumen saat membutuhkan suatu produk akan terlintas nama dari brand tersebut.

\section{Purchase Intention}

Menurut Kotler dan Keller (2012, p. 296), purchase intention adalah "consumer behaviour occur when consumer stimulated by external factors and cometo purchase decision based their personal characteristics and decision making process". Berdasarkan uraian definisi tersebut, maka dapat disimpulkan bahwa purchase intention adalah intensi yang timbul dalam diri seseorang sebelum melakukan pembelian terhadap suatu produk berdasarkan pengalaman dalam menggunakan produk tersebut, lalu berdasarkan penilaian atas suatu produk tersebut yang sudah dibuktikan sebelumnya atau dapat pula terjadi karena adanya penilaian dari faktor eksternal sehingga mempengaruhi proses keputusan pembelian.

\section{Kaitan antara Country of Origin dengan Purchase Intention}

Penelitian yang dilakukan oleh Cho dan Haliun (2015) serta Parkvithee dan Miranda (2012) menyatakan bahwa country of origin berpengaruh positif dan signifikan terhadap purchase intention. Mereka menyatakan bahwa merek dari asal negara tertentu yang dimana negara tersebut merupakan negara maju atau dipandang akan meningkatkan purchase intention dari diri seseorang untuk melakukan pembelian atas produk tersebut.

H1 : Terdapat pengaruh positif country of origin terhadap purchase intention

\section{Kaitan antara Brand Image dengan Purchase Intention}

Penelitian yang dilakukan oleh Ghaizani, Pangestuti dan Rahma (2018), Yu, Lin dan Chen (2013) serta Diamantopoulus, Schlegemilch dan Palihawadana (2011), mengungkapkan bahwa brand image memiliki pengaruh positif terhadap purchase intention. Diungkapkan bahwa brand image yang sudah tertanam baik dalam benak konsumen akan selalu menjadi penunjang yang mempengaruhi keputusan konsumen.

$\mathrm{H} 2$ : Terdapat pengaruh positif brand image terhadap purchase intention

\section{Kaitan antara Brand Awareness dengan Purchase Intention}

Penelitian yang dilakukan oleh Eliasari dan Sukaatmadja (2017), Monarch dan Wiryawan (2012), Hakim dan Keni (2020), serta Orlando (2015) menyatakan bahwa brand awareness berpengaruh postif terhadap purchase intention. Hal ini dapat dijelaskan semakin tinggi tingkat kesadaran merek seseorang, maka purchase intention konsumen terhadap produk dengan merek tersebut meningkat dikarenakan merek tersebut yang pertama kali diingatnya.

H3 : Terdapat pengaruh positif brand awareness terhadap purchase intention

Berdasarkan uraian pengertian dan keterkaitan antar variabel, maka berikut adalah model penelitian:

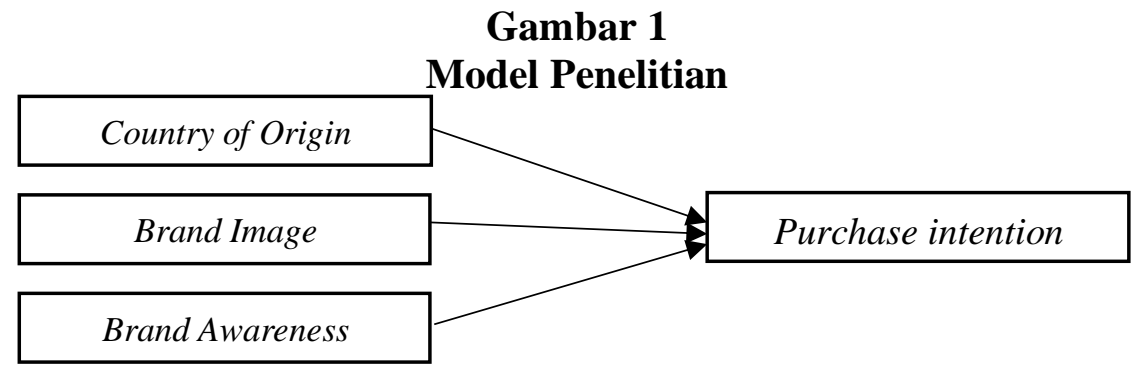




\section{METODOLOGI PENELITIAN}

Dalam penelitian ini, jenis penelitian yang digunakan adalah penelitian deskriptif. Populasi yang dilibatkan adalah orang yang mengetahui produk skincare tersebut dan sampel nya adalah orang yang mengetahui produk skincare tersebut serta berdomisili di Jakarta. Penyebaran data menggunakan kuesioner melalui Google Form. Sampel yang digunakan dalam penelitian ini adalah sebanyak 212 orang, mayoritas responden berumur 22-25 tahun $(59,4 \%)$, berdomisili di Jakarta Barat $(72,2 \%)$ dan berpenghasilan $<\mathrm{Rp} 8.000 .000-\mathrm{Rp}$ 12.000.000 (38,2\%). Teknik analisis data yang digunakan adalah PLS-SEM dengan bantuan software Smart PLS. Indikator penelitian yang digunakan dalam penelitian ini dapat dilihat pada tabel berikut ini.

\section{Tabel 1}

Indikator Pengukuran Variabel

\begin{tabular}{|c|c|c|}
\hline Variabel & Item & Sumber \\
\hline Country of Origin & 3 item & $\begin{array}{l}\text { Cho dan Haliun (2015) } \\
\text { Ghaizani, Pangestuti dan Rahma (2018) }\end{array}$ \\
\hline Brand Image & 4 item & Ghaizani, Pangestuti dan Rahma (2018); Orlando (2015) \\
\hline Brand Awareness & 4 item & Eliasari dan Sukaatmadja (2017); Orlando (2015) \\
\hline Purchase Intention & 4 item & Cho dan Haliun (2015) \\
\hline
\end{tabular}

\section{HASIL ANALISIS DAN PEMBAHASAN}

Hasil analisis convergent validity (nilai AVE > 0,50 dan loading factor >0,70) lalu discriminant validty (kriteria dari Fornell-Lacker dan nilai cross loading) serta nilai dari composite reliability dan Cronbach alpha menunjukkan nilai > 0,6. Hal ini menunjukkan semua indikator yang peneliti gunakan sudah memenuhi nilai syarat minimum dari metode pengukuran yang digunakan. Hasil uji $\mathrm{R}^{2}$ menunjukkan bahwa country of origin, brand image, dan brand awareness secara bersama-sama memiliki pengaruh kuat terhadap purchase intention dengan nilai 0,633 . Hasil uji $\mathrm{Q}^{2}$ menunjukkan bahwa nilai $\mathrm{Q}^{2}$ yang dihasilkan adalah sebesar 0,459 dimana hal ini menunjukkan lebih besar dari 0. Maka variabel-variabel yang digunakan dalam penelitian ini dapat memprediksi model penelitian yang dibuat dengan baik. Selanjutnya nilai GoF yang dihasilkan adalah sebesar 0,636 yang berarti masuk ke dalam kategori besar, yang artinya model dalam penelitian ini memiliki kecocokan dan kesesuaian. Nilai dari uji path coefficient menunjukkan bahwa variabel country of origin, brand image dan brand awareness memiliki pengaruh positif terhadap purchase intention. Selanjutnya adalah uji effect size atau uji $\mathrm{f}^{2}$, menunjukkan bahwa brand awareness memiliki tingkat prediktor sebesar 0,800. Hasil pengujian bootstrapping disajikan pada tabel berikut:

\section{Tabel 2}

Hasil Analisis Path Coefficient

\begin{tabular}{ccccc}
\hline Hipotesis & Keterangan & $\begin{array}{c}\text { Path } \\
\text { Coefficient }\end{array}$ & t-statistics & p-value \\
\hline $\mathbf{H}_{\mathbf{1}}$ & Country of Origin $\rightarrow$ Purchase Intention & 0,084 & 2,331 & 0,020 \\
\hline $\mathbf{H}_{\mathbf{2}}$ & Brand Image $\rightarrow$ Purchase Intention & 0,036 & 0,238 & 0,812 \\
\hline $\mathbf{H}_{3}$ & Brand Awareness $\rightarrow$ Purchase Intention & 0,733 & 14,913 & 0,000 \\
\hline
\end{tabular}

Berdasarkan tabel diatas menunjukkan bahwa nilai $t$-statistics dari country of origin terhadap purchase intention adalah sebesar 2,331 yang berarti lebih besar dari syarat minimun yaitu 1,96 dan nilai $p$-value sebesar 0,020 yang lebih kecil dari 0,05 . Oleh karena itu, dapat disimpulkan dari pengujian hipotesis bahwa $\mathrm{H} 1$ tidak ditolak. Hasil penelitian ini didukung oleh hasil penelitian yang dilakukan oleh Cho dan Haliun (2015) serta Parkvithee dan Miranda (2012), yang menyatakan bahwa country of origin berpengaruh positif terhadap purchase intention.

Selanjutnya, nilai $t$-statistics dari brand image terhadap purchase intention adalah sebesar 0,238 yang berarti lebih kecil dari syarat minimum yaitu 1,96 dan nilai $p$-value sebesar 0,812 yang lebih besar dari 0,05. Oleh karena itu, dapat disimpulkan dari pengujian hipotesis bahwa $\mathrm{H} 2$ ditolak. Hasil penemuan ini tidak sejalan dengan penelitian yang telah dilakukan 
oleh Ghaizani, Pangestuti dan Rahma (2018), Yu, Lin dan Chen (2013), serta Diamantopoulus, Schlegelmilch dan Palihawadana (2011), dimana mereka menyatakan bahwa brand image memiliki pengaruh positif signifikan terhadap purchase intention. Namun, hasil hipotesis kedua dari penelitian ini didukung oleh hasil penelitian dari Demante dan Dwiyanto (2019) yang mengemukakan bahwa brand image tidak mempengaruhi purchase intention.

Terakhir, nilai $t$-statistics dari brand awareness terhadap purchase intention adalah sebesar 14,913 yang berarti lebih besar dari syarat minimun yaitu 1,96 dan nilai $p$-value sebesar 0,000 yang lebih kecil dari 0,05. Oleh karena itu dapat disimpulkan dari pengujian hipotesis pada tabel 4.23 diatas bahwa $\mathrm{H} 3$ tidak ditolak. Hal ini sesuai dengan penelitian yang dilakukan oleh Eliasari dan Sukaatmadja (2017), Monarch dan Wiryawan (2012) serta Orlando (2015), yang menyatakan ahwa brand awareness berpengaruh positif signifikan terhadap purchase intention.

\section{KESIMPULAN DAN SARAN}

Hasil penelitian ini menunjukkan bahwa country of origin dan brand awareness memiliki pengaruh yang positif signifikan terhadap purchase intention. Sementara itu brand image memiliki pengaruh positif tidak signifikan terhadap purchase intention. Hasil penelitian ini juga menunjukkan bahwa brand awareness dan country of origin, secara berurutan, merupakan prediktor terbesar terhadap perubahan naik turunnya purchase intention, sedangkan brand image tidak dapat memprediksi perubahan pada purchase intention.

Penelitian ini diharapkan dapat memberikan kontribusi yang baik. Pertama, mayoritas responden beranggapan bahwa negara tersebut merupakan negara yang baik. Hal ini mempengaruhi responden dalam melakukan pembelian atas produk skincare tersebut. Peneliti menyarankan kepada perusahaan untuk selalu menanamkan bahwa brand skincare ini berasal dari negara tersebut. Perusahaan tetap dapat melakukan promosi yang sebelumnya sudah dilakukan oleh perusahaan di sosial media seperti Instagram, twitter, facebook dan youtube dengan menunjukkan wajah-wajah brand ambassador dari brand tersebut yang berasal dari negara tersebut. Selain itu, perusahaan bisa juga menggunakan cuplikan di drama dari negara tersebut yang biasanya terdapat scene built in (promotion) mengenai brand-brand yang digunakan oleh aktor dan aktris nya, salah satunya adalah brand perusahaan ini, sehingga diharapkan dengan ini customer lebih aware bahwa produk skincare ini berasal dari negara tersebut. Kedua, hasil dari penelitian ini menunjukkan bahwa brand awareness atau tingkat pengetahuan konsumen terhadap eksistensi brand ini sudah tertanam dengan baik di konsumen. Hal ini ditunjukkan dengan adanya pengaruh positif antara brand awareness dengan purchase intention. Saran dari peneliti untuk perusahaan adalah untuk tetap mempertahankan design dan ciri khas dari brand ini yaitu yang mengusung tema air. Adanya konsistensi dari sebuah brand atas ciri khasnya menandakan bahwa brand tersebut memiliki standar atau kualitas yang tidak akan berubah sehingga konsumen akan selalu meningat produk dari merek ini apabila membutuhkan produk sejenis. Selain itu, diharapkan agar perusahaan selalu meningkatkan kualitas dan ingredients dari produk skincare itu melalui research kebutuhan setiap jenis kulit serta melakukan demonstrasi dan review atas hasil yang diperoleh oleh beberapa customer pilihan dengan cara membuka stand atau booth di mall-mall. Lalu dapat membuat skincare routine dengan menggunakan brand ini di platform online.

\section{DAFTAR PUSTAKA}

Cho, S., \& Haliun, S. (2015). The effects of Korean country-of-origin on Mongolian consumer product evaluation and purchase intention. Journal of Marketing and Consumer Behaviour in Emerging Markets, 1(1), 4-14. https://doi.org/10.7172/24496634.jmcbem.2015.1.1

Demante, K., \& Dwiyanto, B. M. (2019). Analisis pengaruh electronic word of mouth terhadap brand image dan perceived quality serta dampaknya pada purchase intention (Studi pada 
lipstik sariayu Martha Tilaar di Kota Semarang). Diponegoro Journal of Management, 8(4), 97-105.

Diamantopoulos, A., Schlegelmilch, B., \& Palihawadana, D. (2011). The relationship between country-of-origin image and brand image as drivers of purchase intentions: A test of alternative perspectives. International Marketing Review, 28(5), 508-524. https://doi.org/10.1108/02651331111167624

Eliasari, P. R., \& Sukaatmadja, I. P. G. (2017). Pengaruh brand awareness terhadap purchaseintention dimediasi oleh perceived-quality dan brand-loyalty. E-Jurnal Manajemen Universitas Udayana, 6(12), 6620-6650.

Ghaizani, A., Pangestuti, E., \& Rahma, L. D. (2018). Pengaruh country of origin terhadap brand image dan dampaknya bagi keputusan pembelian (Survei online pada konsumen skin care Etude House di Indonesia). Jurnal Administrasi Bisnis, 58(2), 110-118.

Hakim, L. L., \& Keni. (2020). Pengaruh brand awareness, brand image dan customer perceived value terhadap purchase intention. Jurnal Manajemen Bisnis Dan Kewirausahaan, 4(3), 81-86. https://doi.org/10.24912/jmbk.v4i3.7921

Hamzaoui, L., \& Merunka, D. (2006). The impact of country of design and country of manufacture on consumer perceptions of bi-national products' quality: An empirical model based on the concept of fit. Journal of Consumer Marketing, 23(3), 145-155. https://doi.org/10.1108/07363760610663303

Hong, S.-T., \& Wyer, Jr., R. S. (2017). Determinants of product evaluation: Effects of the time interval between knowledge of a product's country of origin and information about its specific attributes. Journal of Consumer Research, 17(3), 277. https://doi.org/10.1086/208557

Keller, K. L. (2013). Strategic brand management: Building, measuring, and managing brand equity (4th ed.). Pearson Education Inc.

Kim, N., Chun, E., \& Ko, E. (2017). Country of origin effects on brand image, brand evaluation, and purchase intention: A closer look at Seoul, New York, and Paris fashion collection. International Marketing Review, 34(2), 254-271. https://doi.org/10.1108/IMR-03-2015-0071

Kotler, P., \& Keller, K. L. (2012). Marketing management (14th ed.). Prentice Hall.

Monarch, R., \& Wiryawan, Z. (2012). Pengaruh brand awareness terhadap perceived quality dan brand loyalty sebagai determinan terhadap purchase intention (Studi kasus: Teh Botol Sosro di Pasar Festival Kuningan, Jakarta). Jurnal Manajemen, 16(3), 299-311.

Orlando, D. (2015). Analisa pengaruh brand image dan brand awareness terhadap purchase intention Kawasaki Ninja 250Fi. Jurnal Strategi Pemasaran, 3(1), 1-9.

Parkvithee, N., \& Miranda, M. J. (2012). The interaction effect of country-of-origin, brand equity and purchase involvement on consumer purchase intentions of clothing labels. Asia Pacific Journal of Marketing and Logistics, 24(1), 7-22. https://doi.org/10.1108/13555851211192678

Rossiter, J. R., \& Percy, L. (2014). Advertising and promotion management. McGraw-Hill Book Company.

Santoso, D. A., Erdiansyah, R., \& Pribadi, M. A. (2019). Pengaruh brand awareness dan brand image terhadap minat beli produk kecantikan Innisfree. Prologia, 2(2), 286-290. https://doi.org/10.24912/pr.v2i2.3589

Winarto, F. G. (2010). Enzim pangan. M-Brio Press.

Yu, C., Lin, P., \& Chen, C. (2013). How brand image, country of origin, and self-congruity influence internet users' purchase intention. Social Behavior and Personality, 41(4), 599-611. https://doi.org/10.2224/sbp.2013.41.4.599

Zap Clinic. (2018). Survey skincare terhadap wanita. https://zapclinic.com/zapbeautyindex 